InOdia $\quad \begin{aligned} & \text { InMedia } \\ & \text { The French Journal of Media Studies }\end{aligned}$

8.1. $\mid 2020$

Ubiquitous Visuality

Screen resistance: New Anatomies of Beauty?

Emmanuelle Delanoë-Brun

(2) OpenEdition

Journals

Electronic version

URL: http://journals.openedition.org/inmedia/2072

DOI: 10.4000/inmedia.2072

ISSN: 2259-4728

Publisher

Center for Research on the English-Speaking World (CREW)

Electronic reference

Emmanuelle Delanoë-Brun, "Screen resistance: New Anatomies of Beauty?", InMedia [Online], 8.1. I

2020, Online since 15 December 2020, connection on 27 January 2021. URL: http://

journals.openedition.org/inmedia/2072 ; DOI: https://doi.org/10.4000/inmedia.2072

This text was automatically generated on 27 January 2021.

(c) InMedia 


\title{
Screen resistance: New Anatomies of Beauty?
}

\author{
Emmanuelle Delanoë-Brun
}

1 "Hollywood films shape and express the way we see-and don't see-our bodies, our selves," in an industry where today "director and dialog matter less to box office take, while bodily spectacle and blasting sound matter more," Chris Holmlund writes. ${ }^{1}$ Spectacular bodies, always the staple of popular cinema, fashion our definitions of gender categories, delineating the realm of the masculine and the feminine. ${ }^{2}$ In their superlative visibility, they also establish what bodies are socially acceptable, and tolerable, relegating "impossible bodies"-minority bodies, ageing bodies, nonstandard bodies-to the margins of visuality.

2 The fashion and cosmetic industry redouble this dominant discourse of the body beautiful attuned to the liberal ideology of personal responsibility and selfaccomplishment. Oversized, magnified bodies spread over giant billboards have become a fixture of the contemporary metropolitan cityscape. ${ }^{3}$ They are, massively, young, female bodies, lithe and firm, supple and energetic in their moves. They are seductive bodies, staring unabashedly into the camera or averting their faces the better to draw attention to their fetishized parts. They are wealthy bodies, professional bodies, or in turn bodies enjoying the comforts of leisurely activities or lazy reposeemotional and communal bodies, surrounded by friends and family, active, performative bodies dealing out a tale of perpetually renewed success and happiness for the price of whatever products they happen to be selling. Screens big and small give additional resonance to their visibility as they keep popping up on our mobile devices, with which we in turn produce images of our bodies beautified via countless apps for further circulation. The body beautiful, fashioned at the movies and promised by commercial culture, is constantly paraded as the ultimate signifier and capital of our liberal societies, caught in an economy of permanent exposure.

In such a context, is there any room left for alternative discourses on the body, on screen? The recent fad for superhero franchise films, predicated on the parading of superhuman bodies and capabilities actualized as shows of powerful masculinity and 
supportive femininity, testifies to the obvious supremacy of the sexually polarized body beautiful-a body that is also superlatively white, western, young, heterosexual, shaped by self-discipline rather than the contingencies of work and class. As the rise of cultural studies drew critical attention to such popular vehicles as ideological constructs, feminist, queer and post-colonial approaches exposed the politics of invisibility, as well as the gender, class or racial stereotyping Hollywood products validate and enforce. What of the Black body, the Asian body, the Latino body?, became the rallying cry as the new century dawned. ${ }^{4}$ What of the ageing body? ${ }^{5}$ What of the gay or lesbian body, the transgender body, the queer body, the gender-fluid body? ${ }^{6}$ What of the disabled body, the large body, the quirky body, the body as physical, social, political experience of forms of social control predicated on dominant norms of cultural and political hegemony? Quite clearly, body visibility charters new territories of the marginal, the invisible, and the obscene, territories that come with obvious political ramifications.

Focusing on the female body as most visually exposed, and most codified as both object of pleasure and vehicle of consumption, I examine the way in which recent screen discourses gradually seek to accommodate or re-channel such challenges to the body beautiful as a site of capitalistic incarnation and dominance. ${ }^{7}$

\section{The woman in the TV mirror: fracturing the cosmetic gaze?}

5 In the late 1990s, Sex and the City participated to the definition of a fashionable, hip, glitzy, sexually liberated, self-absorbed form of femininity grounded in obsessive attention with looks and a show of independence largely predicated on male approval. Twenty years later, as Lena Dunham's New York show Girls opened on HBO in 2012, a poster of the former hit served as ironic backdrop to the portrayal of struggling twenty-somethings no longer desperate to adjust to the highly sophisticated model of privileged confidence and seductiveness. Dunham's girls look nothing like their glamorous predecessors, nor do they necessarily try to. As the pilot establishes in its opening scene, their bodies are much less exhibited as displays of femininity than as experiences of bare necessities, as Annah, the protagonist, is presented negotiating a mouthful of pasta while her parents are discussing terminating her allowance to give her the final push into responsible adulthood. ${ }^{8}$ Constantly recusing its ironical title, Girls strips the girl show of its defining elements of romance, sexiness and fantasies of vicarious girl-power: the approach is brashly unglamorous as Annah exhibits her less than perfect face and physique, sizes up her belly while positioning her body for sex with her superlatively plain boyfriend in frontal shots that steer clear of fetishization, or panics over sexually transmitted diseases and condom failures.

6 First aired in 2012, Girls marks a shift in the representation of female characters on the TV screen, testifying to a new generation of female creators' irritation with dominant models of controlled femininity and idealizations of the female body. As the show became a hit of its own, its claim to the truthfulness of the contemporary young female experience came under attack as still blatantly white, privileged, heterosexual, and blind to its own social, racial and cultural biases. Still, both the show and the critical response it garnered point to new forms of televisual engagement with the issue of the body beautiful, signaling a growing awareness of the virulence of the "cosmetic gaze" and its impact on female audiences. 
7 "What we experience in today's beauty discourse [...] is a bettered self that has been reborn from its own flesh and is now, like a digitally remastered character from a classic Hollywood movie, immortal," Bernadette Wegenstein writes in her study of the forcefulness of what she calls "the cosmetic gaze." Grounded in platonic ideals of selfharmony, the cosmetic gaze postulates an identity of inner and outer selves that fed $18^{\text {th }}$ century expectations of physiognomic profiling and $19^{\text {th }}$ century fantasies of phrenological classifications, before degenerating in $20^{\text {th }}$ century abjections of ethnic purifications. Partially divested of its moral backdrop via the capitalistic individualization of social destiny, yet invested with ideological suspiciousness, the cosmetic gaze resurfaced with the explosion of the visual culture and mediatization of the body as evidence of self, garnering newfound strength in the liberal culture of selfresponsibility and improvement, of capitalization of self.

8 The cosmetic gaze commands our vision of self as perfectible, informed by the techniques and processes of physical improvement, adjusted to definitions of beauty as success and accomplishment of self that are largely established in Western standards. It makes higher demands on women, whose social identity remains massively predicated on visual performance of femininity. The publicity given to female stars' beauty and fitness routines, much as the before/after dialectics of popular television makeover shows, establishes standards of visibility by ostracizing signs of age, body fat, excess skin, irregularities of shape, flaccidity of skin or muscle, lack of fashion expertise. Experts and coaches are mobilized to perfect the science of being beautiful and healthy, anatomizing the female body into parts that each require specific attention. The beauty industry in turn becomes more and more atomized, with the opening of countless centers targeting singular body parts-nail salons, eyebrow clinics-often couched in the language of science to conflate issues of beauty and health.

The discipline of beauty is enforced by a system of visual polarization that targets sins of negligence as much as excess attention. Sites and magazines in profusion exhibit photographic evidence of the ravages of truth on unmade-up celebrity faces, the ugly reality of their body-parts "au naturel," or the monstrous outcome of botched or excessive plastic jobs, telling the tale of the spectacle of femininity as an aesthetic as much as moral obligation on women, against a monstrous unfeminine. In the 1950s, age was a marker of the monstrous unfeminine as hysterical and grotesque masquerade of femininity, in such classics as Sunset Boulevard, or Whatever Happened to Baby Jane? ${ }^{10}$ Invisibility was the natural destiny for women past their feminine and cosmeticized bloom. In the super-exposed 2010s, the monstrous unfeminine has become a simple matter of deviance from the dominant cosmetic script as the booming beauty industry makes constantly renewed promises of defying the works of time and biology via observance of strict beauty routines, fitness programs and diets. Issues of image control have become paramount to the performance of femininity as faultless self-discipline and subjection to the dominant standards of beauty.

In such a context, issues of alternative visual modes of being a woman, within or without the visual script of femininity, also take pride of place. The 2017 \#dresslikeawoman Twitter campaign made it clear as it responded to yet another of president Donald Trump's sexist remarks shaped by the media discourse of which he is, as former host of a popular TV show, a representative. It is a challenge that a handful of television series also meet, offering critical visual narratives of the female body and extending the perimeter and definition of female visibility on screen. 
11 The approach may be direct, as in AMC's recent Dietland, that ran for one season in 2018. Centered on the character of Alicia "Plum" Kettle, the large shadow-writer to Kitty Montgomery, the super-slim publisher of a young girls' magazine, the series tackles the oppressive nature of the cosmetic gaze head-on, as Plum struggles with issues of body acceptance and the prospect of yet another diet. Plum writes from a position of uncomfortable entrenchment, as the voice of a fashion and beauty industry that rejects everything she represents, and from within a society that considers her as a laughable joke. Issues of visibility are central to the character, who is intensely aware of the nature of the gaze she originates and has internalized, a gaze materialized as the slimmer silhouette of herself in a fetching scarlet dress she projects in the inner mirror of her tormented self-consciousness.

Once again, the approach is resolutely unglamorous, as the series sets out to expose the fabric of the cosmeticized body Plum aspires to. One episode has a former reality TV star coach Plum towards "bangability" in a sarcastic attempt to get her to question her goal of catering to the male gaze and its uncertain promises of emotional and sensual rewards. ${ }^{11}$ The project brazenly lifts the veil on the undocumented pragmatics of the cosmetic gaze, as Plum is waxed out of all body hair, subjected to the outrageously expensive routine of facial enhancement at a select beauty salon, then forced into torturous belly-tucking and hip-reducing "invisible" contraptions to be able to fit into a form-flattering dress. Usually an invisible process fascinating only in the revelation of its glorified end-result, beautification is exhibited as an experience in costly and painful humiliation that stigmatizes the female body as essentially faulty.

Julianna Margulies's Kitty Montgomery, by contrast, features the oppressive visibility of the female body as cosmetic construction. As a female editor in an essentially male world controlled by male money, she is seen constantly securing a precarious position in her transparent office, while her power is only proportionate to the cultural value credited to the beauty discourse among women-a beauty discourse the show gleefully undercuts and deconstructs as masquerade and performance. In one scene Julia Smith, the former beauty expert to Montgomery's magazine, divests herself of her costume of femininity. ${ }^{12}$ Standing before a mirror, Smith sheds the symbols of her controlled femininity-the smooth wig covering her nappy hair, the high heels, the eyelashes and foundation, the corset, the silicon paddings in her bra-to reveal the reality of her mature, imperfect body to Plum, a body marked by time and the scars of breast cancer, a black body alien to the dominant standards of beauty that wealthy, aristocratic, white-skinned Montgomery stands for. Reversing the process of the "reveal" moment in makeover shows, where the made-over contestant is revealed her new self, carved out of her formerly imperfect body, Smith explodes the fantasy of a truth of beautified self as sheer artifice and grotesque puppetry with a racist and classist twist.

Three years earlier, a similar "reverse reveal" moment was staged in How to Get Away with Murder, a legal murder thriller that targeted a much larger audience than the openly militant Dietland. In a scene that marked the apex of episode four of the first season, ${ }^{13}$ Viola Davies as Annalise Keating is similarly shown divesting herself of her armor of controlled femininity and exposing her unadorned face to her vanity mirror. Cast as a power-driven defense attorney and university professor, Davies plays a character whose social identity comes through as a show of forceful authority invested in her impeccable grooming and headstrong bossing of students. What the moment reveals then, in the quietude and solemnity of the extended scene, is the tiresome 
weight the performance of femininity lays on the character. Femininity is exposed as a mask, a bag of visible tricks, as the character's face gradually emerges from the layers of wig, eyelashes, heavy foundation, lipstick, penciled brows and eyeshadow. Yet far from re-actualizing the moral anxieties with female guile and seductiveness that the cosmetic gaze has long been disseminating, ${ }^{14}$ the muted image, shot in intimate close ups, works as a moment of moving intimacy of self, a moment of liberation from overwhelming standards of perfection and control.

What surfaces is what the beauty discourse has rendered invisible, literally obscene, only to be exposed as the monstrous unfeminine in the sensational beauty press and media: the character's actual face conflated with the actress's, the actress's face, as truly her own, merging through the character's-a moment of fascinating facial striptease, vertiginous in its conflation of truth and fiction. The monstrous unfeminine is embraced, divested of its obscene invisibility, rewritten as sober intimacy of self in the general beauty parade of feminine identity. Recaptured from the cosmetic gaze as much as from the male gaze whose toll of masquerade, seductiveness, and selfalienation it exposes, it is validated as an authentic reveal, when "body and body image are finally one: feeling, affect, and movement match-for once, and however brieflyappearance, exterior and reflection." ${ }^{15}$ And obviously, the moment also works as a claim for visibility couched in racial terms, further politicizing the issue: the cosmetic gaze emerges as shaped in the dominant terms of white beauty standards seeking to suppress the black body via cosmetic assimilation.

\section{Television and movie bodies: the politics of screen visibility}

16 How to Get Away with Murder makes no claim to realism. Quite the opposite even, as every new season weaves an impossible tale of personal vendettas, family secrets and romantic entanglements. The approach is anchored in traditions of soapy melodramas, revamped by constant dramatic thrills and generous displays of erotic encounters. The formula is an old popular one, zested up to accommodate the progressive identity, gender and sexual politics of its creators. The liberalization of the media market and explosion of the streaming platforms in the 2010s encouraged such a trend by mechanically amplifying former niche markets. While reality TV shows and syndicated programs continue catering to the tastes of the most popular segments of the audience, ${ }^{16}$ numerous shows address expectations of less stereotyped, more sophisticated and diverse characters reverberating issues too long ignored in the mainstream media.

When it first aired in 2011, American Horror Story embraced the challenge by literally going for the repressed, mobilizing and re-actualizing classic tropes of popular gothic fiction to expose the rejects of the cosmetic gaze. What emerges as a result is the "freak show" of a culture obsessed by youth, looks, health and ability, and a general show of white privilege. ${ }^{17}$ American Horror Story rewrites the Barnum of popular entertainment culture into a sophisticated, elaborate narrative hall of mirrors, a perverse, eerie exploration of the dark underside of America's glamorous vision of self, and history. Targeting a more fictionally conservative audience titillated by the show's daring casting of a Black female lead, How to Get Away with Murder's mixture of sexy-soapycrime drama and direct, unflinching approach to issues of the female body, race, class 
or LGBTQ sexuality in particular testifies to how popular vehicles are also affected by expectations of social awareness and fracturing of the ideological/cultural status-quo.

In 2015, Viola Davis became the first African American actress to win an Emmy award for best drama actress for her part in How to Get Away with Murder. In her acceptance speech, she vigorously lamented the persistence of a color line in the media industry. "The only thing that separates women of color from anyone else is opportunity. You cannot win an Emmy for roles that are simply not there," Davis hammered, before proceeding to thank the creators and show runners, Shonda Rhimes prominent among them, "who have redefined what it means to be beautiful, to be sexy, to be a leading woman. To be black."

The same year, Frances McDormand reaped an Emmy for best actress in a mini-series for her role as Olive Kitteridge in the eponymous mini-series. ${ }^{18}$ The 2014 award had gone to Jessica Lange for her role as Delphine Lalaurie in the gothic show American Horror Story. Katie Bates won best supporting actress in the same show, for which Angela Bassett had also been nominated. While Davis's outcry at the lack of racial diversity in leading television shows cannot be disputed, evidence still points to a female diversification of television parts in the recent years, in shows that all in their way work at exposing a rejection of the dominant cosmetic gaze and beauty discourse. Mc Dormand's Olive Kitteridge was an abrasive retired teacher with a talent for getting under people's skin, including her son's and her doting husband's.

American Horror Story turned on the gothic to investigate issues of women's ageing, tragic obsession with looks, and repeated monstrous marginalization and exploitation over the course of centuries from an intersectional, racially aware perspective, offering former stars an assortment of challenging parts. Orange is the New Black is yet another case of a show parading female diversity and divergence from standard expectations of color, age, beauty, class and demeanor, even though the show initially revolves around a privileged white society girl precipitated into the adverse environment of a female state prison. The premise, though, is turned into an ironic opportunity to showcase much less standard female characters while the lead protagonist's position is rapidly renegotiated as part of the ensemble cast.

In the last ten years, American prominent television fiction shows have thus largely become a platform for the exploration and promotion of social, cultural, racial, gender identity politics and the development of a liberal militant agenda. Boosted by the boom in streaming platforms, they have become a privileged mode of raising awareness, even in their more popular products. How to Get Away with Murder's intended viewership is not American Horror Story's: the generic bracket, conservative focus on matters of law and order, or romantic inclination, together with the largely stereotypical distribution of secondary characters and reliance on a high dosage of dramatic twists, calibrates the show for a large, popular audience looking for classic thrills. Which is precisely what makes its agenda of advancing the cause of black female visibility all the more remarkable, along with its challenge to the cosmetic gaze, or more general attack on social norms and stereotypes.

Studies of the popular reception of the most popular television shows point to a highly polarized cultural map on the American territory both socially and politically.$^{19}$ Correlated with polling results on the wake of the 2016 presidential election, they also point to the political resonance of their ideological agenda and importance of their socio-economic and ethnic reach. By way of comparison, in 2016, a survey conducted by 
the Motion Picture Association of America documented how movie-going audiences were still predominantly white, for an industry appealing massively to family audiences and the younger, professional 18-39 age bracket. ${ }^{20}$ Yet it was noted as part of the general movie trends that " $[\mathrm{t}] \mathrm{hree}$ of the top five grossing films in 2016 attracted majority female audiences." ${ }^{21}$

The number of female leads in big buck movies is also rising consistently, marking a gradual shift in Hollywood's traditionally conservative sexual politics. Rogue One, the second highest grossing movie of 2016 and a prequel to the Star Wars franchise, revolved around Jyn Erso (Felicity Jones) as female lead to a band of rebels against the Galaxy's growing tyranny. Erso remains fully dressed in practical combat browns throughout the film, which made no attempt to pair her with a romantic interest, while her heroic sacrifice in the end marks the beginning of the saga. Star Wars, the Force Awakens, which made it to top 10 the same year, introduced the character of Rey (Daisy Ridley) as a female aspiring Jedi to the still embattled rebellion, among a diversified crew including John Boyega as stormtrooper Finn and Lupita Nyong'o as voice and body model to the CGI character of Maz Kanata. A year later, together with Kelly Mary Tran as technician Rose Ticoor and Laura Dern as Vice Admiral Amilyn Holdo, Rey returned in Star Wars, the Last Jedi. The film finished top of the grossing list, while Wonderwoman made it to number 3 on the domestic market. ${ }^{22}$ This came after Mad Max, Fury Road captivated audiences worldwide in 2015, despite the titular hero being relegated to secondary position as a dispensable source of energy and Charlize Theron as Furiosa taking the lead.

Together with the wave of female-focused reboots and all-female vehicles that have hit the screens since, the wave of female-driven blockbusters attracted a great deal of media and militant attention: was Hollywood going feminist and postcolonial all of a sudden, paying long overdue homage to women and minorities while reaping big dollars through vehicles still massively directed and controlled by men? ${ }^{23}$ Was the brand of feminism the right one, which still centered mostly on pretty young white female characters, no matter how muted their sexuality was? Was it right when it focused on rewriting the narratives of men, still organizing their fictional representation around a male universe, along masculine lines? ${ }^{24}$ Or conversely, was it the end of narratives of white male herohood, if not of manhood altogether, under a coordinated attack of an industry suddenly gone madly liberal? After Ghostbusters' allfemale remake got buried under a barrage of Internet and Twitter attacks complaining of the film's betrayal of the 1984 spirit of non-partisan (though all-male) fun, the social media became ablaze with ire and calls to boycott films daring to question established gender norms, rallying massive support in response against the violent backlash.

The evolution taking place on the TV serial market generated far less media agitation, testifying to the cultural and symbolical weight Hollywood still carries. While television probes the experience of bodies evolving outside of the cultural, generic, heteronormative, racial norm, Hollywood operates from within the dominant norm it serves to establish in correlation with the social and cultural market it still massively caters to and to whom it must deliver promises of entertainment and spectacle in a context of growing media competition. The bodies Hollywood delivers remain, then, spectacular bodies, parading deviation from the norm as central to their performance of exceptionality. 

intent on liberating a handful of objectified sex slaves from Immortan Joe's patriarchal hell, Theron delivers a show of outstanding body efficacy and mastery of combat, smooth and supple in every choreographed move. The character's relative sexlessness in combat make-up and gear is established against a backdrop of stereotyped models in long flowing hair, flimsy fabrics, wan porcelain faces and firm limbs-Joe's slave wives, the film's visibly ironical take on the cosmetic body of the beauty discourse. Still, the sooty make-up only serves to highlight the clear green eyes of the Hollywood star, just as the large support belt emphasizes the super-slim waist and curvy hips in closefitting pants, while the camera lingers on muscular arm, perfectly shaped skull, or again eyes cameoed in the rear-view mirror, fetishizing body parts. Furiosa's character may be extricated from the narrative of female objectification and body exploitation vilified by the movie, but the actress's body remains entangled in its visual dynamics, her gracelessness clarified as performance, activating the cosmetic-and male-gaze the film purports to invalidate. The unglamorous eventually translates as violence porn, as the character must suffer the consequences of her deviation in her body, a female Christ-like figure of self-sacrifice, before she is hailed as liberating mother to Immortan Joe's legions of famished children. Liberation from objectification, in the end, amounts to the restoration of other forms of gender stereotypes in a film glorifying nurturing motherhood as the alternative to aggressive patriarchy.

Felicity Jones's Erso, or Daisy Ridley's Rey, belong in the same pattern of deobjectification and normalcy as performance within a body trained for efficacy. Their controlled plainness becomes a marker of their exceptionality, the better to relish in the demonstration of their body operativeness. Bodily spectacle remains central to Hollywood female representation, predicated on the cosmetic gaze, while alternative bodies are distributed as supportive parts and comforted in their peripheric status to the centrality of young, white, slim, controlled femininity, which persists as default mode to the cinematographic industry.

\section{The woman in the picture: Hollywood's re-incarnated muses?}

Hollywood produces the dominant cosmetic gaze television altogether reverberates, amplifies and questions; and it is because their position is still being negotiated on the cultural market as a voice of legitimized authority that television series have let in creators with a more militant agenda who often operate from within relegated genressoaps, legal dramas, horror shows. Hollywood's response to the explosion of the media market has been to secure its position as producer of ever bigger, larger, splashier films, higher on sensational impact and spectacular bodies. It is within this diet, generally low on political calories, that Hollywood is responding to demands for more diversity on screen and less sexualization of the female body. Transported onto the movie screen, issues of the female body take on a different resonance then, no longer articulated around the political body of social interaction within a defined cultural scope but redirected towards concerns with the fabric of representation and exemplarity, couched in terms both of image-value, and body efficacy. The figure of the muse returns, the inspiring female heroine absorbed in issues of body image, entangled in the cosmetic gaze.

InMedia, 8.1. | 2020 
29 In a long sequence from the latest of the Star Wars franchise film, protagonist Rey penetrates a dark cave in the hope of receiving information on her Jedi parenthood. Standing in front of a dull mirror, she finds herself reverberated to infinity on the cave walls, multiple versions copying her every move and word. The scene is unexpectedly long and quiet, a solemn moment focused on the character's hope for a revelation, which comes anticlimactically as self-revelation, as it is her face she finds in the mirror instead of her parents'. Rey's face is pale as she probes her claim to herohood, via lineage. It is her body that stands forth, multiplied ad infinitum, while she tries on slight, muted gestures, a body she seems to be testing, or whose operativeness in the chain of reproductions she is trying-snapping her fingers, extending her hand, whispering soft words of command to the cave wall. Rey's version of herohood is deliberately toned down, articulated onto a body whose singularity is called into question and whose gender markers have been all but defused in her bland, covering clothing and minimal makeup. The intensity of her stare defines her identity in terms of determination, and emotional potency, rather than show of force, or seductiveness. Yet in the end, it remains trapped in the circularity of self-image, a revelation that comes as a shock to the character, divested of a truth of self.

30 While male characters remain caught up in tropes of explosive action and demonstrations of singular prowess, or wrapped up in aspirations of dark hegemony and show of brutality, two classic modes of masculine herohood and villainy, Star Wars, the Last Jedi displaces attention towards the female protagonist called upon to try her hand at a different mode of hero(in)hood. The move is not isolated, as Hollywood is more and more loudly called upon to steer away from the dominant show of hegemonic masculinity it has long favored. Still, the new script of female agency comes with a renewed focalization on the female body, and specifically with its engagement with its own reflection, and mediality. Challenged in the modalities of its problematic visibility, the female cinematic body articulates anxieties of self-alienation, and dissociated corporeality, entrenched in image and functionality.

31 Similar questions agitate Denis Villeneuve's 2018 Blade Runner 2049. One of the highlights of the film has protagonist $\mathrm{K}$ confront a gigantic holographic projection of Joi, his former female virtual companion, in the rainy city night. The gigantic body, all fluorescent pink and electrifying blue hair, wonders at the loneliness of the diminutive male figure, then squats and extends her finger as if to touch him, only to be revealed as a commercial advertisement for the model of which she was only a standard issue. In the short sequence, Villeneuve captures the spirit of anxiety and wonder that the film agitates, as replicant-and replicant hunter $-\mathrm{K}$ is overwhelmed by the visual memory of the hologram that used to accompany him and give a semblance of normalcy to his solitary existence. How do we engage the body-in particular the female body-as image, in the surrounding commercial and cosmetic culture that informs the film's futuristic dystopia? Can images ever steer free of the stereotypical commercial and social scripts that contribute to shape them-and ourselves as consumers of images? Is there a way out of the body-as-image vs body-as-function dichotomy that the figures of the hologram and the replicant metaphorize?

32 Joi's spectacular body, projected onto the backdrop of bleak dark buildings in a city drenched in perpetual rain, is a jacked-up version of the compliant geisha girls who used to populate the giant screens that lit up the city in Ridley Scott's original 1984 Blade Runner. In the 40 years that separate the two films, oversized screens and gigantic 
billboards have materialized in our daily lives what in Scott's film was only the vision of a drab future, and spectacular bodies have invaded city space, amplifying the normative discourse on the body beautiful that both Hollywood, the fashion and the cosmetic industry have developed over the course of the $20^{\text {th }}$ century. As anxieties over the virtualization of our reality translate into film after film, from the Wachowskis' 1999 The Matrix to Spielberg's 2018's Ready, Player One, activating over and over the fantasy of a resistance to the collapse of reality and its materialistic politics, bodily spectacle continues to function as the driving force in our media environment, a contradiction whose ultimate poignancy Villeneuve's film addresses, as the male protagonist is literally left to investigate the remains of a woman's body among replicas of synthetic flesh and images. All the while, the "miracle" of incarnation and birth evades K, the film's frustrated would-be Adam.

The triumph of bodily spectacle is the flip side of the "erasure of embodiment" that to Katherine Hayles is characteristic of our contemporary culture obsessed with the posthuman. ${ }^{25}$ In Ridley Scott's 1984 Blade Runner, it was Rachael, the picture-perfect secretary shaped as a male fantasy out of a 1940 s pin-up catalogue, who came to symbolize the predicament of the would-be subject caught in the trap of the surrounding visual culture. Rachael whose status-human? android?-is being investigated and tested, while a fascinated Deckard both seeks to humanize and objectify her. Can Rachel love, can she desire, can her body and her mind respond to Deckard's emotional and erotic involvement in her body and mind, are some of the many questions the film raises in a problematic scene, which has the male protagonist enforcing his desire on the female character he is supposedly introducing to her essential humanity. How does the body and the conundrum of passions, reticences, fears, curiosities, perceptions, thoughts and vague emotions it encapsulates as self, inhabit a world of images it both partakes in and is shaped by?

Forty years later, the question still resonates in Villeneuve's sequel, which has a replicant protagonist investigate the remnants of Rachel's body while her lookalikes populate his environment in the form of holograms (Joi) or androids (Luv). But while it was Rachael's soul and identity as desiring subject that had captured Deckard's attention as he investigated the android's claim to emotions and memories and to the full spectrum of sensory and sensitive experience, Villeneuve's sequel obsesses much more with issues of the body-replicant, holographic, photographed, statufied, anatomized-as K traces the descent of Rachael, whose bone remains he comes upon in the opening sequence of the film. Preoccupations with essence have shifted to concerns with embodiment, with the evasive sense of being inscribed in the materiality of body as much as the fabric of consciousness, in a film saturated with images, projections, figurations of women. It is among these images, holograms and statues that $\mathrm{K}$ sets out to find the new Eve, a woman incarnate.

K's solitary existence is partially relieved by the presence of Joi, the life-size hologram who perfectly conforms to sexist scripts of female seductiveness, companionship and domesticity and whom he can switch on and off at will. The only thing Joi lacks is a body, something she remedies by hiring Mariette, a replicant whose function it is to pleasure men. To consummate her relationship with $\mathrm{K}$, Joi morphs her image with Mariette's body, achieving some form of surrogate incarnation and completing her destiny as the male hero's erotic and emotional provider. K's world is one of synthetic women and virtual female bodies, glamorous images straight out of fashion magazines 
and Hollywood stereotypes such as Luv, the Wallace corporation replicant who follows him in his quest, who appears as yet another version of Rachael. ${ }^{26}$

Yet the female body, whose material traces and descent $\mathrm{K}$ seeks, is only inscribed in one more stereotypical male fabrication of the female essence, the myth-the "miracle"-of childbearing, and motherhood. Reimagined as the posthuman age's new Eve, Rachael is sacralized as the mother of a new generation of human hybrids, for whom she literally gives her life. Dr. Ana Stelline, her daughter, ends up living in an enclosed universe, a segregated Eden of fabricated images, isolated from the infection of the outside world of collapsed reality in her sanctified, literally alienated body. Villeneuve's sequel rewrites Scott's masterpiece into a nightmare of female exploitation and alienation, surrounding his melancholy hero with ravaged muses as projections of a male culture of fantasized female, as ultimate representations of the strictly functional, operative virtualized body.

Villeneuve has holographic ballerinas or naked Joi models feature the problematic status of the body as image, as concept "collapsed in its mediality," divorced from its corporeality ${ }^{27}$-a body dematerialized, virtualized, broken down into functions and applications. Tom Ford's sophisticated 2016 psychological thriller Nocturnal Animals on the other hand explodes the cinematographic trope of the woman in the picture in its striking opening credit sequence, which has five aged, white, overweight naked models dance lasciviously before scarlet drapes. The women only wear burlesque accessorieswhite gloves, hats and boots, glittery lipstick, flags and party sticks. Glitter first comes showering down against a dark background, then the image fades to reveal the bare midsection of the first dancers, in extreme close up, projecting voluminous, sagging breasts and folds of flesh onto the screen. The dancers then come into focus in full shot, moving in slow motion to the soft violin music, in flattering low-key lighting. Each woman is shot individually, captured in the specificity of her moves, looking straight into the camera, or twisting around, exhibiting a body marked by age, surgery sometimes, a body in excess of all the standards of beauty, yet uninhibitedly playing the game of seduction. The final moments in the credit sequence return to close ups of the model's faces, sometimes blurred, sometimes in focus, challenging the viewer whom they look in the face from a slightly low angle.

Once the credit sequence is over, it is revealed that the women are part of an art installation of giant screens set up in a select art gallery, which also exhibits the bodies of these women lying on large white slabs, while visitors at an opening circulate between them. The contrast between visitors and art is extreme, with bodies trained to discipline and self-display on the one hand and bodies of uncensored amusement and self-indulgence on the other. Susan Morrow (Amy Adam), the gallery owner, is introduced as the antithesis to the art she presents: rigid, motionless, impeccably dressed in designer clothes, her body controlled, her face made, her hair tamed. Shot from either a wide angle or in extreme close-ups concentrated on her lips, her eyes, intersected with images of road exchanges in extreme large shots, suggesting the inner agitation and emotional emptiness of the character whose psyche is caught up in images of pointless circulation.

The women in the art are not part of the narrative: they feature as the artwork Susan Morrow shows but is entirely divorced from. The lack of inhibition and sense of sheer enjoyment they exhibit highlights the cold, controlled world of visual and social perfection Morrow inhabits. By contrast, Morrow's body is statuesque, a monument of 
design and control, a body denied incarnation to function as fashion and social image, a symbol of self-accomplishment which the film then deconstructs as self-alienation. A character directly out of Tom Ford's glamorous world of designer sophistication and wealth, Morrow articulates the anxieties of the liberal subject as construction of selfimage, against the unabashed bodies of women confident in their carnality, whose self appears anchored in body experience and exfiltrated from the cosmetic gaze and beauty discourse.

\section{Conclusion}

The contemporary body experiences itself as projection, and project, as circulated image and spectacle of self, signifying contemporary ease and liberation, and the success story of existence and identity. Its imperative is to look good and be healthy in the liberal culture of individual responsibility, encouraging a whole business of cosmetic and physical improvement combining diets, fitness, healthy living and the occasional surgery to erase its subjection to the logics of time, genetics and biology. Once our common lot and destiny, the body has become our individual project, the marker of an identity to be inscribed in the spectacle of its conformism to the dominant discourse of bodily success and self-realization. The body-as-image is also a body-asinstrument, to be subjected to carefully monitored routines and controls so as to perform its operative function. It is a disciplined body, a testimony to self-control and self-production, a body as accessory and commodity-a body not so much experienced as instrumentalized, and mediatized. As such, the superlative body of media discourse is paradoxically disembodied, freed of organic destiny and material contingences, focused on performance of self and the identity politics of the liberal subject.

41 As the new millennium progressed, then, it seemed as if issues of the virtualization of the body, the body as artifact, image and accessory, as functional or cosmetic commodity, loomed large, inscribed in the dominant visual narrative of the western body, both operative and beautiful. Still, how is this virtual body to be reconnected with the pragmatic, physical, social and political realities of the experienced, phenomenological body? How can this western body concept be divested of the complex ideological backdrop it wraps into a glamorous, glitzy package oblivious to the material realities of the socialized, political body? The question was raised, brutally, as on $9 / 11$, the millennium also opened on the horrendous spectacle of bodies eradicated en masse, desecrated bodies covered in ash and dust, falling bodies, caught in the power politics of clashing world views.

How is the "erasure of embodiment" that the mediatized or posthuman body entails to be reconciled with the very carnal, flesh-and-bones body of experience? How is the cultural fantasy of a dematerialized, glorified, singular body to fit in with the spectacle of large-scale bodily exploitation and violence that make up considerable portions of our daily news, exposing the social, economic and geo-political realities of our professed post-historical, post-industrial, post-modern and post-human world? Cinema, publicity and the media's infatuation with spectacular bodies, celebrity bodies, and the beauty, health, wealth, race and gender politics they ostensibly parade has orchestrated a new form of social and cultural control over what is visible of this body, and more largely what bodies are visible, what states and conditions of the body are visually acceptable. 
It is precisely such frontiers of bodily visibility that are being challenged, either directly or indirectly, on screens big and small, attacking the edifice of the body beautiful as young, white, energetic, successful, lithe and fit. The dawning of the virtual age of disincarnated beauty and performance of self paradoxically corresponds with the reemergence of a fascination for the intensely corporeal, carnal, corruptible body in the mainstream cultural sphere as a new body of visibility. Yet it is upon this paradoxical consecration of the body as virtual and carnal, singular and multiple, idealized and brutalized, liberated and tightly controlled, desiring and instrumentalized, that contemporary visual narratives of the body are being articulated and gradually integrated into alternative discourses of the body.

\section{BIBLIOGRAPHY}

Amiel, Vincent. Le corps au cinéma. Paris: Presses universitaires de France, 1998.

Chivers, Sally. The Silvering Screen: Old Age and Disability in Cinema. Toronto, Buffalo, London: University of Toronto Press, 2011.

Courtine, Jean-Jacques, ed. Histoire du Corps: Tome 3. Les mutations du regard. Le XXe siècle. Paris: Editions du Seuil, 2006.

Dolan, Josephine. Contemporary Cinema and 'Old Age': Gender and the Silvering of Stardom. London: Palgrave Macmillan, 2017.

Ethis, Emmanuel and Jean-Louis Fabianni, eds. "Body is comedy: Figures du corps au cinéma." Culture et musées 7 (2006).

Game, Jérôme, ed. Image des corps/corps des images au cinéma. Paris: ENS Editions, 2010.

Gefford, Susan. Hard Bodies: Hollywood Masculinities in the Reagan Era. New Brunswick [NJ]: Rutgers UP, 1994.

Gentile, Kathy Justice, ed. Sexing the Look in Popular Visual Culture. Newcastle: Cambridge Scholars, 2010.

Gray, Herman. Watching Race: Television and the Struggle for Blackness. Minneapolis: University of Minnesota Press, 2004.

Gwynne, Joel (ed.). Transgression in Anglo-American Cinema: Gender, Sex and the Deviant Body. New York: Columbia UP, 2016.

Hayles, N. Katherine. How We Became Posthuman: Virtual Bodies in Cybernetics, Literature and Informatics. Chicago: University of Chicago Press, 1999.

Hess, Amanda. “The Trouble with Hollywood Gender Flips.” New York Times, June 12, 2018. https://www.nytimes.com/2018/06/12/movies/oceans-8-gender-swap.html.

Holmlund, Chris. Impossible Bodies: Femininity and Masculinity at the Movies. London and New York: Routledge, 2002. 
Holson, Laura M. "Latinos Are Underrepresented in Hollywood, Study Finds", New York Times, August, 26, 2019. https://www.nytimes.com/2019/08/26/movies/latinos-hollywoodunderrepresented.html

Jones, Meredith. "Media-Bodies and Screen-Births: Cosmetic Surgery Reality Television." Continuum: Journal of Media \& Cultural Studies 22, no. 3 (2008): 515-24.

Katz, Josh. "Duck Dynasty vs Modern Family: 50 Maps of the US Cultural Divide." New York Times, Dec. 27, 2016. https://www.nytimes.com/interactive/2016/12/26/upshot/duck-dynasty-vsmodern-family-television-maps.html.

La Force, Thessaly. "Why Do Asian-Americans Remain Largely Unseen in Film and Television?", New York Times Nov. 6, 2018. https://www.nytimes.com/2018/11/06/t-magazine/asian-americanactors-representation.html

Motion Pictures Association of America. “Theatrical Market Statistics 2016.” Accessed February $9^{\text {th }}, 2020$. https://www.mpaa.org/wp-content/uploads/2018/03/MPAA-Theatrical-MarketStatistics-2016_Final-1.pdf.

Richardson, Nial. Ageing Femininity on Screen: The Older Woman in Contemporary Cinema. London and New York: IB Tauris, 2019.

Sender, Katherine. The Makeover: Reality Television and Reflexive Audiences. New York: New York UP, 2012.

Smith, Anna. "A Force for Good: Why The Last Jedi is the Most Triumphantly Feminist Star Wars Movie Yet." The Guardian, Dec. 18, 2017. https://www.theguardian.com/film/2017/dec/18/starwars-the-last-jedi-women-bechdel-test.

Tasker, Yvonne. Spectacular Bodies: Gender, Genre and the Action Cinema. London and New York: Routledge, 1993.

The Numbers, “Annual Movie Chart 2017," accessed February $9^{\text {th }}$ 2020, https://www.thenumbers.com/market/2017/top-grossing-movies.

Vigarello, George. Histoire de la beauté: Le corps et l'art d'embellir de la Renaissance à nos jours. Paris: Seuil, 2004.

Wegenstein, Bernadette. Getting Under the Skin: Body and Media Theory. Cambridge [Mass.] and London: MIT Press, 2006

---. The Cosmetic Gaze: Body Modification and the Construction of Beauty. Cambridge [Mass.] and London: MIT Press, 2012

American Horror Story. Created by Ryan Murphy. FX, 2011-.

Blade Runner. Directed by Ridley Scott. Warner Bros, 1982.

Blade Runner 2049. Directed by Denis Villeneuve. Warner Bros, 2017.

Dietland. Created by Marti Noxon. AMC, 2019.

Ghostbusters. Directed by Paul Feig. Sony Pictures, 2016.

Girls. Created by Lena Dunham. HBO, 2012-17.

Her. Directed by Spike Jonze. Warner Bros, 2013.

How to Get Away with Murder. Created by Peter Nowalk. ABC, 2014-. 
Mad Max: Fury Road. Directed by Goerge Miller. Warner Bros, 2015.

Matrix (The). Directed by Lana and Lilly Waschowski. Warner Bros, 1999.

Nocturnal Animals. Directed by Tom Ford, 2016.

Olive Kitteridge. Created by Lisa Cholodenko. HBO, 2014.

Ready, Player One. Directed by Steven Spielberg. Warner Bros, 2018.

Rogue One: A Star Wars Story. Directed by Gareth Edwards. Walt Disney Studios, 2016.

Sex and the City. Created by Darren Star. HBO, 1998-2004.

Star Wars: The Force Awakens. Directed by J. J. Abrams. Walt Disney Studios, 2015.

Star Wars: The Last Jedi. Directed by Rian Johnson. Walt Disney Studios, 2017.

Sunset Boulevard. Directed by Billy Wilder. Paramount, 1950.

Whatever Happened to Baby Jane. Directed by Robert Aldrich. Warner Bros, 1962.

Wonderwoman. Directed by Pat Jenkins. Warner Bros, 2017.

\section{NOTES}

1. Chris Holmlund, Impossible Bodies: Femininity and Masculinity at the Movies (London and New York: Routledge, 2002), 3.

2. Yvonne Tasker, Spectacular Bodies: Gender, Genre and the Action Cinema (London and New York: Routledge 1993).

3. New-York based photographer Natan Dvir documents the phenomenon in his Coming Soon series, in particular, visible on atandvir.com/gallery/coming-soon/.

4. The viral \#OscarsSoWhite protest campaign gave unprecedented resonance to these issues of media representation in 2015. Since then, numerous articles have been berating Hollywood's, and more largely television's lack of inclusivity. See Thessaly La Force, "Why Do Asian-Americans Remain Largely Unseen in Film and Television?" New York Times, Nov. 6, 2018, https:// www.nytimes.com/2018/11/06/t-magazine/asian-american-actors-representation.html. Laura M. Holson, "Latinos Are Underrepresented in Hollywood, Study Finds", New York Times, Aug. 26, 2019, https://www.nytimes.com/2019/08/26/movies/latinos-hollywood-underrepresented.html.

5. Though Josephine Dolan notes how the changing demographics of cinema goers is making ageing bodies more visible on movie screens, she studies how the ageing star is still very much held up to standards of youthful beauty and performance (Contemporary Cinema and old Age: Gender and the Silvering of Stardom, London: Palgrave Macmillan 2017). See also Sally Chivers, The Silvering Screen: Old Age and Disability in Cinema (Toronto, Buffalo, London: University of Toronto Press, 2011) and Nial Richardson, Ageing Femininity on Screen: The Older Woman in Contemporary Cinema (London and New York: IB Tauris, 2019).

6. Transgression in Anglo-American Cinema: Gender, Sex and the Deviant Body (New York: Columbia UP, 2016), edited by Joel Gwynne, examines the marginal visibility of such non-normative bodies in independent films, and of alternative visual discourses of femininity and masculinity.

7. The male body would deserve a separate study of its own, in line with Susan Gefford's work on the male body on screen in the 1980s (Hard Bodies: Hollywood Masculinity in the Reagan Era, New Brunswick, NJ: Rutgers UP, 1994), or Yvonne Tasker's study of the male action hero in Spectatular Bodies (1993).

8. "Pilot", S01E01, written and directed by Lena Dunham, broadcast originally on HBO on April $15^{\text {th }}, 2012$. 
9. Bernadette Wegenstein, The Cosmetic Gaze: Body Modification and the Construction of Beauty (Cambridge [Mass.] and London: MIT Press, 2012), $\mathrm{x}$.

10. See Sally Chivers, "Baby Jane Grew Up: The Horror of Ageing in Mid-Twentieth Century Hollywood," chapter 2 of The Silvering Screen, 38-56.

11. S01E04, "F... This", directed by Michael Trim, originally broadcast on AMC on June $18^{\text {th }}, 2018$.

12. S01E06, "Belly of the Beast", directed by Amy York Rubin, broadcast originally on AMC on July $2^{\text {nd }}, 2018$.

13. S01E04, "Let's Get to Scooping", directed by Laura Innes, broadcast originally on $A B C$ on October $16^{\text {th }}, 2014$.

14. Bernadette Wegenstein retraces the long tradition of assimilating female beauty to trickery and falsehood, a form of hypocrisy to be decoded, against the moraly virtuous natural beauty of the male figure ("Lavater's Concept of Female Beauty: Devotion vs Masquerade", in Chapter 1 of The Cosmetic Gaze, 13-22),

15. Meredith Jones, "Media-Bodies and Screen-Births: Cosmetic Surgery Reality Television," Continuum: Journal of Media \& Cultural Studies 22, no. 3 (2008):517, in Bernadette Wegenstein, The Cosmetic Gaze, 53.

16. Katherine Sender, The Makeover: Reality Television and Reflexive Audiences (New York: New York UP, 2012).

17. Freak Show is the subtitle to season 3 of this anthological series (October 2014 - January 2015). Characters directly inspired by Todd Browning's picture though already feature prominently in Asylum, AHS's second season.

18. Olive Kitteridge, created by Lisa Cholodenko, a 4 episode mini-series, aired on HBO in November 2014.

19. In "Duck Dynasty vs Modern Family: 50 Maps of the US Cultural Divide," New York Times writer Josh Katz studied the popularity of prominent TV programs in the United States. Clear dividing lines emerge between mostly urban watchers of more sophisticated, liberal-minded fiction shows, and the mostly rural watchers of reality soaps of the Duck Dynasty variety. Outlining the close relationship between culture and politics in light of the 2016 presidential election, the article seeks rare "points of unity in a splintering culture" (Dec. 27, 2016). https:// www.nytimes.com/interactive/2016/12/26/upshot/duck-dynasty-vs-modern-family-televisionmaps.html

20. In 2016, only 11 percent of the American and Canadian population were considered as regular movie-goers (viewers attending cinema once a month or more), accounting for $48 \%$ of all tickets sold. Caucasians made up most of this frequent viewer population (51\%, at 18.3 million), followed by Hispanics ( 8.3 million) and African-Americans (5.6 million), “Asians and Others" making up for the last 3.9 million viewers. Women viewers were proportionately slightly more numerous than male viewers ( $52 \%$ of the viewing population, while they account $51 \%$ of the overall population). The 18-39 age brackets represented $42 \%$ of the total amount of filmgoers, while they make up $32 \%$ of the general population. All statistics from: "Theatrical Market Statistics 2016," Motion Pictures Association of America, accessed February 09, 2020, https://www.mpaa.org/wpcontent/uploads/2018/03/MPAA-Theatrical-Market-Statistics-2016_Final-1.pdf.

21. "Theatrical Market Statistics": 4.

22. "Annual Movie Chart 2017," The Numbers, accessed February 09, 2020, https://www.thenumbers.com/market/2017/top-grossing-movies.

23. Anna Smith, "A Force for Good: Why The Last Jedi is the Most Triumphantly Feminist Star Wars Movie Yet," The Guardian, Dec. 18, 2017, https://www.theguardian.com/film/2017/dec/18/starwars-the-last-jedi-women-bechdel-test. Smith enthuses over how the film is the first blockbuster to massively pass the Bechdel test, offering visions of women in all forms of positions of social integration, from political assembly to line of command to technical functions, while pointing to 
the directorial limbo in which such a feast is still achieved, with hardly any woman in command of large budget vehicles, and none at all in the blockbuster category.

24. Amanda Hess, "The Trouble with Gender Flips," New York Times, June 12, 2018, https:// www.nytimes.com/2018/06/12/movies/oceans-8-gender-swap.html.

25. N. Katherine Hayles, How We Became Posthuman: Virtual Bodies in Cybernetics, Literature and Informatics (Chicago: University of Chicago Press, 1999), 4.

26. Spike Jonze's 2013 Her raises echoing questions of disembodiement and virtualization of both body and self, as Theodore Twombly (Joaquim Phoenix) falls in love with the voice of his virtual assistant, "played" by an invisible Scarlet Johanson.

27. Bernadette Wegenstein, The Cosmetic Gaze, $\mathrm{x}$.

\section{ABSTRACTS}

If "Hollywood films shape and express the way we see-and don't see-our bodies, our selves" (Chris Holmlund, Impossible Bodies, 3), in an industry where "director and dialog matter less to box office take, while bodily spectacle and blasting sound matter more" (Ibid.), is there any room left for alternative discourses on the body on screen? While the dominant discourse of bodily spectacle looms large, with the development of franchise films in the past decade in particular, sensibilities to what bodies do what on screen, and how, have developed, testifying to a complex spectatorial engagement with the phenomenon. Meanwhile, television series have secured their slot in the entertainment business, competing with multi-million-dollar feature films for viewers' attention. And while bodies on screen are still central to their attractiveness, the nature of these bodies begs attention: a gangly crew of children in Stranger Things, nerds and geeks in The Big Bang Theory, all matter of grotesque characters in American Horror Story, an African American female lead in How to Get Away with Murder or Scandal. As Hollywood regularly struggles with accusations of whitewashing and sexism in its most popular vehicles, popular TV fiction chips at the ideological edifice, promoting a more diverse visual environment. Yet it is a challenge that a handful of films are also trying to meet, encountering opposition proportionate to their intended viewership. This article examines how resistance to the promotion of "spectacular bodies" is developing on screens large and small and how bodily spectacle has become a political and cultural battleground. Attention focuses primarily on the female body and how its relationship to beauty as a generic expectation is problematized, concentrating on recent tv shows, (How to Get Away with Murder, Dietland, Girls), and films (Nocturnal Animals, Tom Ford, 2016 and Blade Runner 2049, Denis Villeneuve, 2017).

\section{INDEX}

Keywords: Hollywood films, TV series, corporeality, cosmetic gaze, femininity 


\section{AUTHOR}

\section{EMMANUELLE DELANOË-BRUN}

Emmanuelle Delanoë-Brun is a lecturer at Université de Paris, where she teaches literary translation and visual arts. She is co-author of The House of Mirth, Edith Wharton, Terence Davies: Anatomie d'une illusion (PUF, 2012). She has published and communicated on the works of Robert Altman, Stanley Kubrick, John Sayles, among others, Terrence Malick, Michael Cimino, Terence Davies. Her more recent research focuses on television series, particularly genre series, and on the links between literature and seriality.

Université de Paris, LARCA, CNRS, F-75013 Paris, France

delanoee@univ-paris-diderot.fr

en 